\title{
INFORMATION TECHNOLOGY-BASED MANAGEMENT EDUCATION IN VOCATIONAL HIGH SCHOOLS
}

\author{
Rita Aryani, and Leroy Holman Siahaan \\ Sekolah Tinggi Keguruan dan Ilmu Pendidikan Panca Sakti, Bekasi \\ J1. Raya Hankam No.54, Jatirahayu, Pondok Melati, Kota Bekasi, Jawa Barat, 17414 \\ E-mail: ritaar1757@gmail.com;leroyholmansiahaan@gmail.com
}

\begin{abstract}
This study aims to analyze the role of information technology-based management education in vocational schools. The implementation of technology was conducted in several schools, covering managerial aspects as well as academic aspects. This research utilizes a qualitative approach and descriptive method. Data obtained through literature review and analyzed descriptively and qualitatively. The results show that technology-based management education is essential to provide information to support and facilitate the management and academic processes daily. Schools must invest in technology-based school systems to increase the effectiveness and efficiency of school management generally.
\end{abstract}

Keywords: management; education; information technology; vocational high school

\section{PENDIDIKAN MANAJEMEN BERBASIS TEKNOLOGI INFORMASI DI SEKOLAH TINGGI KEJURUAN}

\begin{abstract}
ABSTRAK. Penelitian ini bertujuan untuk menganalisis peran pendidikan manajemen berbasis teknologi informasi di sekolah kejuruan. Implementasi teknologi dilakukan di beberapa sekolah, meliputi aspek manajerial serta aspek akademik. Penelitian ini menggunakan pendekatan kualitatif dan metode deskriptif. Data diperoleh melalui tinjauan pustaka dan dianalisis secara deskriptif dan kualitatif. Hasil penelitian menunjukkan bahwa pendidikan manajemen berbasis teknologi sangat penting untuk memberikan informasi untuk mendukung dan memfasilitasi proses manajemen dan akademik setiap hari. Penting bahwa sekolah berinvestasi dalam sistem sekolah berbasis teknologi untuk meningkatkan efektivitas dan efisiensi dalam manajemen sekolah secara umum.
\end{abstract}

Kata kunci: manajemen; pendidikan; teknologi informasi; sekolah

\section{INTRODUCTION}

Educational management is the study of how to organize resources to achieve goals that have been set productively and how to create a good atmosphere for people who participate in achieving goals that are mutually agreed upon.

In the National Education System Law Article 1 paragraph 1 (UU Nomor 20 Tahun 2003, 2003), it is said that Education is a cognizant exertion to make an environment of learning and learning measure so understudies effectively build up their capability to have strict otherworldly quality, poise, character, insight, respectable character, and the aptitudes required by them, society and country.

The purpose of management education is closely related to the objectives of education in general because management education is essentially a tool to achieve educational goals optimally. Education management is a process that needs to be applied in the world of education so that the goals of education can be achieved. Management is a process of planning and controlling resources to produce something effective. If linked in the world of education, then the ultimate goal is in education. Management will shape the education to be more directed so that the results will be better.

Another goal of management education is the creation of students who are active in developing their capability to have strict profound quality, discretion, knowledge, respectable ethics, and the aptitudes required without anyone else. Thus, the child will be useful in society, nation, and country. So, education management is important to implement. School management is the most important factor in organizing education and teaching in schools whose success is measured by the achievements of graduates, therefore in running leadership, must think "information system" means in the administration of education in schools related components such as teachers, staff, parents of students/ community, government, students, and others must function optimally which is influenced by the policies and performance of leaders by promoting information technology.

Such a rapid challenge will be overcome if the influence of school leadership is concentrated on achieving the intended goals. The influence of the principal's leadership besides catching up to overcome the challenges mentioned above, such as: creating openness in the process of providing education and teaching with information technology that connects science and practice to achieve a certain aim and target (Dahil, Karabulut \& Mutlu, 2015). Creating a work climate based on information technology can be fun by implementing management functions in the process of organizing education, such as organizing planning, determining staff, being able to provide guidance and coaching towards accelerating is a control of all activities of the slightest deviation can be found so quickly resolved. 
For education to be more effective and efficient according to the needs and objectives, management activities in the field of education are needed as alternatives to the implementation of education, and as an effort to organize education so that the future development of the education world regarding the desired goals. Besides, management education also aims as a form of search or determination of actions to be taken that are oriented to the future. So, it convinces certain parties rationally that education will be carried out effectively and efficiently.

Nowadays education in the world is increasingly competitive, competitors in the education field are getting tougher. Efforts to improve learning, provision of facilities, and human resources to establish good relations for cooperation with various related parties. In vocational high schools, the use of information technology is also a factor in success and advancement in the quality of learning.

Information technology in vocational high schools in the future is not the only function as a supporting tool but as the main weapon as a support for educational success so that it can hold well. It also, as Telem, Barta and Levin, becomes an instrument to promote school leadership, change introduction and management and, for teaching and learning evaluation (1997, p.31).

The mindset of human resources must be built early to follow the development of information technology that is developing very fast. An educator must be trained to think about how to form students who are creative, critical, innovative, and also have an entrepreneurial spirit and can solve problems by utilizing information technology as Gogus and Saygin (2019) suggest in their study that High School students (20\%) spend more than 4 hours per day on the Internet.

Therefore, this study aims to find out, analyze, and describe the role of information technology-based education management in vocational high schools to overcome problems by utilizing information technology in education. With the role of information technologybased education management for the world of education, it can produce quality human resources that will improve the conditions of education accompanied by other improvements.

\section{Education Management}

Educational management is the art and science of managing educational resources to make a climate of learning and learning measures so understudies effectively build up their capability to have profound quality, poise, character, insight, respectable characters, and the abilities required without anyone else, the country's locale and nation.

Educational management is an effort that focuses on the process of managing and coordinating various educational resources such as teachers, educational facilities, and infrastructures, such as libraries, laboratories, and so on to achieve educational goals and objectives. Educational management is also indirectly involved in educating the life of the nation, developing whole people, possessing knowledge and skills, a solid and independent personality, and a sense of togetherness and national responsibility.

Besides, education management is a matter that must be prioritized for the continuity of education, to produce the desired impact. Many educational institutions do not have good management in managing their education. Visionary education, having a clear mission will produce quality output. That's where the importance of management education is applied.

Educational management is the study of how to organize resources to achieve goals that have been set productively and how to create a good atmosphere for people who participate in achieving goals that are mutually agreed upon.

Tilaar (2012: 225) Understanding education management according to Tilaar is an activity that implements educational plans or plans.

Understanding education management according to Hamalik (2007), is to unite several elements in education and then try to be developed and focus on achieving the goals of educational management itself.

So, it can be synthesized that education management is everything related to managing the educational process to achieving the goals set, both short-term medium-term goals, and long-term goals.

\section{Information Technology}

According to Warsita (2008: 135), information technology is infrastructure (hardware, software, user) systems and methods for obtaining, sending, processing, interpreting, storing, organizing, and using meaningful data. The same thing was expressed by Lantip and Riyanto (2011: 4) information technology is defined as science in the field of computer-based information and its development is very rapid.

Technology can be expected to be a facilitator. Initially, information technology was used only limited to data processing. With the growing development of information technology used only limited to data processing. Access to global information resources, peer-teams communication, and communication links between individuals and team members are among the internet services supporting educational management (Barta \& Telem, 1997).

Information Technology is the study or electronic equipment, especially computers, for storing, analyzing, and distributing any information, including words, numbers, and images (Hornby, 1995). Information Technology is a technology that combines computing (computers) with high-speed communication lines that carry data, voice, and video (William \& Sawyer, 2003).

This information technology is a combination of computer technology that consists of hardware and software to process and store information with communication technology to channel information. 
Here communication technology is used as a means of channeling information while the information is processed and stored on a computer. From some of the definitions above information technology includes a combination of computer technology and telecommunications technology itself. Computer as hardware with software that serves as a means of processing and storing data that will be sent via communication channels.

\section{The Role of Information Technology-Based Education Management}

The development of information technology in recent years has been developing at a very high speed. So, this development has changed and made people paradigm in finding and obtaining information, which is no longer limited to newspapers, audio-visual and electronic information, but also other sources of information through the internet.

One of the fields has had a significant impact with the development of this technology in the field of education, where education is a process of communication and information from educators to students containing educational information, which has educative elements as sources of information, media as a means of presenting ideas, ideas and educational material as well as the students themselves (Oetomo and Priyogutomo, 2004), some elements of this element get a touch of media technology information.

The development of increasingly sophisticated information and communication technology provides opportunities for the world of education to continue to improve quality and achieve educational goals. Information technology is the infrastructure that can be used to collect or provide information that organizations need accurately and without spending a lot of time so that it accelerates organizational performance.

The role of information technology-based education management can be seen in school administration activities, for example, teacher abscesses are now no longer manual but use fingerprints, besides that many software can be used to manage the data of all school stakeholders. Technology-based education is a system that utilizes technology to the greatest extent possible in teaching and learning activities. The technology that has been widely developed for Education is in the electronic fields such as computers and the Internet and it should be flexible, react quickly and be able to anticipate change (Mäkelä, 1997: 23).

The use of technology in the education process has become a basic requirement. Countries with the best education systems compete with each other in creating and developing technology to support the education process.

\section{METHOD}

The author uses a qualitative approach and literature study method with descriptive-qualitative analysis data obtained through various relevant sources and references as well as related scientific studies.
A qualitative approach is a comprehensive approach or strategy for finding or obtaining the required data. An approach is a process, principle, and procedure that we use to approach problems and find answers. The approach is influenced or based on the theoretical perspective that we use for conduct research, while the theoretical perspective itself is a framework of explanation or interpretation that allows researchers to understand data and connect complicated data with other events and situations.

Like the theory, the qualitative approach is also measured based on its usefulness, and cannot be assessed whether a method is true or false. To examine the results of research correctly, it is not enough just to see what researchers find, but also how researchers arrive at their findings based on the strengths and limitations of the method used.

The understanding of research methods is trying to understand the specific techniques in research. Some people assume that the research method consists of various research techniques, and some equate the research method with the research technique. But clearly, whatever research methods or techniques we use, whether quantitative or qualitative, must be under the theoretical framework that we assume.

Then, the qualitative approach also makes it easier to deal with double reality, and this approach presents directly the nature of the relationship between researchers and respondents. It is more sensitive and more adaptable to the many attenuations of shared influence and the patterns of values encountered. Therefore, it is expected to be able to analyze more deeply and interpret conditions or relationships.

In conclusion, qualitative approaches are ongoing processes, consequences that are happening, or phenomena that are developing. The study was conducted by analyzing and interpreting the available data. This research emphasizes subjectivity to interpret an issue.

\section{RESULTS AND DISCUSSION}

\section{Information Cycle}

Various kinds of data obtained will be obtained in such a way as to form information that is easily understood and accurate. The following are the stages or cycles needed to produce information: a) collection, b) input, c) management, d) output, and e) distribution.

Many methods are used to collect data. Data is a recorded fact about an object. Retrieval of data can use the sampling method. In the process of inputting the data obtained is input into the application system and processed. Processing activities following existing procedures. At the output stage, the output of the processed data will be displayed in the form of complete information. Appearances can be seen as soft on a computer or hard as a report. The results of information that have been processed and intact will be distributed to relevant parties. Example: 
the final grade of an education management student can be seen by all students on a page or site that has been provided.

2. The role of information technology-based education management

a. E-learning

The virtual class, substantially, should be no different from the real class. The lecturer plans to build a virtual classroom and use all technologies that are suitable for the course being taught. An educator should create an effective learning environment following what was planned before, both in terms of planning, organizing, and evaluating classrooms.

E-learning is a form of learning that utilizes electronic media and Information and Communication Technology (ICT) that allows learning material to be delivered to students without the limited learning process in space. E-learning is developing very rapidly from time to time so that it makes learning activities much easier, more effective, and efficient. The success of e-learning programs is supported by several concepts namely information technology, planning, administration, management, and adequate economic tools. It should also be noted the role of the facilitators, lecturers, staff, how to implement, how to adopt new technologies, facilities, costs, and activity schedules.

E-Learning, therefore, can be implemented in vocational high schools that only apply face-to-face learning systems, in Vocational Schools that apply the concept of distance learning. In essence, SMKs are not much different from the lecture process at universities, which of course with the support of appropriate information technology, will be able to facilitate the implementation of e-Learning at the SMK level.

According to Koswara (2006), several teaching strategies can be applied using e-learning technology as follows:

\section{* Learning by doing.}

Learning simulations by doing what you want to learn; an example is a flight simulator, where a prospective pilot can be trained to fly a particular aircraft as he is training with an actual aircraft.

Learning by doing is defined as learning by doing. Learning by doing means that we prioritize acting rather than theorizing. People who do things that they didn't know before, then they willingly do it. as a result, they will know something, that is called "learning by doing".

* Incidental learning.

It is learning something indirectly. For example, studying geography by doing "virtual trips" to tourist areas.

Incidental learning is a form of learning that is experienced by. It has an advantage because the lessons are learned from everyday life experiences that are centered on learners. This kind of learning is learning from life experiences that have a very broad scope such as learning activities from experiences that are consciously designed by students to learning activities from the experience of success and failure that befell yourself.

This kind of learning activity is often not given enough attention by parents, teachers, school principals, and education policymakers because in general the understanding and attention of learning activities are prioritized informal learning that occurs in school spaces designed deliberately systematic and can be controlled by educators and policymakers. The design and control of formal learning activities in schools conducted by teachers (educators) cause learning activities in schools to be dominated by knowledge from teachers and books so that the knowledge gained from informal and incidental learning activities obtained by learners in daily life outside of school is less valued and recognized for its importance for school education.

* Learning by reflection.

Learn something by developing ideas about the subject to be learned by providing initial information.

Learning that merely collects the knowledge conveyed by the teacher to students, and uses knowledge just to answer the exam held by the school. It is to keep away from the meaning of learning for life.

The dominance of formal learning activities is based on classroom learning, which prioritizes learning from books and teachers cause learning not to live, learning that is independent of personal quality involvement, learning that is not directed by oneself, learning that does not touch on the development of attitudes, feelings, emotions, and personality.

This kind of learning is often criticized as a model of capitalist style education that encourages the formation of oppression, and the destruction of the courage to take the initiative to make changes and independence in action.

Learning is a part of the activities of human life; therefore, life and the development of human life are primary. Education serves as a tool to maintain human survival and develop a better quality of life itself. Therefore, learning activities always have goals related to life, following the choices determined by his responsibilities. As an activity that has a purpose for life, learning cannot be separated from the desires, encouragement, and feelings, and self-awareness of the subject of the culprit.

* Case-based learning (CBL).

Learn something based on cases that have occurred on the subject to be studied. This strategy can study material by absorbing information from expert sources about cases that have occurred on the material.

$\mathrm{CBL}$ is the use of various kinds of intelligence needed to confront real-world challenges, the ability to deal with new things, and existing complexities. 
Another comprehension of issue based learning is the instructing strategy with an emphasis on genuine critical thinking, the cycle by which understudies do assemble work, input, the conversation that can fill in as a venturing stone for examinations and examinations, and last reports. Thus, students can be actively involved in learning materials and develop critical thinking skills.

Problem-based learning is a learning approach that presents contextual problems that stimulate students to learn. In classes that apply problem-based learning, students work in teams to solve real-world problems.

CBL is characterized by the existence of real problems as a context for students learning critical thinking and problem-solving skills and gaining knowledge.

CBL is the development of curriculum and teaching systems that stimulate problem-solving strategies and basic knowledge and skills by placing students in active roles as daily problem solvers that are not well structured.

The two definitions above mean that PBL or PBM is a learning atmosphere that is directed by a daily problem.

CBL Model is characterized as a learning model that includes understudies attempting to take care of issues through a few phases of the logical technique so understudies are relied upon to have the option to learn information identified with the issue and simultaneously understudies are required to have aptitudes in tackling issues.

The CBL model turns into a learning approach that tries to apply issues that happen in reality as a setting for understudies in rehearsing how to think basically and gain aptitudes in critical thinking, just as extraordinary to get information just as significant ideas from training material being discussed.

* Learning by exploring.

Learn something by exploring the subject you want to learn. At the exploratory stage, learners are allowed to use the five senses to the maximum extent possible to interact with the environment. From this activity is expected to emerge questions that lead to the development of thought a high level that begins with the words why and how the emergency of these questions is at the same time an indicator of student readiness towards the next phase. While in this phase the teacher's role is to answer student questions, provide questions to guide students to observe, involve students in the scientific process, and hone thinking skills and provide instructions. So, the students' exploration of continues

\section{b. Administrative Activities}

The administration is a technique or way to serve, help, fulfill. Administration refers to the activity or effort to help, serve, direct, or regulate all activities in achieving a goal. The administration is the business and activities related to implementing policies to achieve goals.

Administration in the strict sense is an activity that includes: notes, correspondence, light bookkeeping, typing, agenda. Administration in the broadest sense is the whole process of collaboration between two or more people to achieve goals by using certain infrastructure that is efficient and effective. Following are examples of the role of information technology-based management education in school administration activities:

1) Student Administration

Student administration itself can be defined as the recording of students starting from the admission process until the student graduates from school due to graduation or other reasons. In information technologybased student administration activities that must be input is student data.

The data is completely entered in the form of a student with address, citizenship status, parents' number. Furthermore, in student data, there are also parent data that is used as a complement to student data.

2) Officialdom administration

Staffing administration is all activities/ activities related to the problem of the use of employees or labor, in achieving its objectives. And the purpose of the administrator is to arrange and control all activities in maintaining, developing, obtaining, and using employees under the workload, in achieving predetermined organizational/company goals. Products based on information technology staffing activities are as follows:

a) Teacher and employee attendance

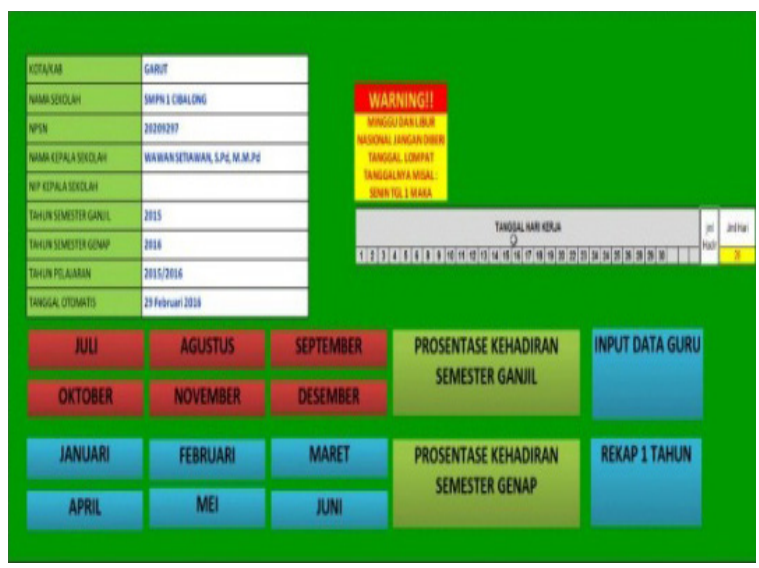

Figure 1. Teacher and Employee Attendance

The teacher's attendance list at school must be physically recorded so that a teacher's attendance can be recapitulated for a certain period. Manually recording the teacher's attendance list can certainly lead to various problems such as scattered data, difficulty in recapitulation to review teacher activity, and so on. With the existence of information technology makes it easy for school administration activities to recap and store teacher and employee absent data. 


\section{b) Teacher and Position Data}

Each school must have a complete teacher database and position. This makes it easier for schools to conduct supervision.

\begin{tabular}{|c|c|}
\hline NAMA & JABATAN \\
\hline Drs Doddy Sularto, MMI & Kepala Sekolah \\
\hline Isye Susilawati, S.Pd. & Guru Mata Pelajaran Matematika \\
\hline Dra. Hj. Ine Heryantini & Guru Mata Pelajaran Ekonomi \\
\hline DR.Hj. Ine Rahayu P, M.Pd. & Guru Mata Pelajaran Biologi \\
\hline Hani Nurhayati, S.Pd. & Guru Mata Pelajaran Ekonomi \\
\hline H. Dadang Mulyadi, M.Pd. & Guru Mata Pelajaran Fisika \\
\hline Dra. Sri Winarni & Guru Mata Pelajaran Matematika \\
\hline Drs. Eman Sulaeman, S.Pd. & Guru Mata Pelajaran PKN \\
\hline Dra. Nani Suryani & Guru Mata Pelajaran Sejarah \\
\hline
\end{tabular}

Figure 1. Teacher data

\section{3) Financial administration}

In organizing education, finance is very important in the education process and the potential that determines the course of an educational process.

The financial component is a component of production that determines the process of conducting activities or teaching and learning in schools with other components. Therefore, all activities carried out by schools require costs both realized and not realized by the education provider. Following is an example of the application of school financial administration:

\section{a) Tuition Fee}

Educational problems are very complex, such as poor academic and service. They should be avoided and eliminated, especially about paying school fees.

The payment system is a system that includes a set of rules, institutions, and mechanisms used to carry out the transfer of funds to meet an obligation arising from economic activity. The payment system is a system that deals with the transfer of a sum of money from one party to another. The media used for the transfer of value for money are very diverse, ranging from the use of simple payment instruments to the use of complex systems that involve various institutions and the rules of the game. So, we should leave the manual method with a lot of problems.

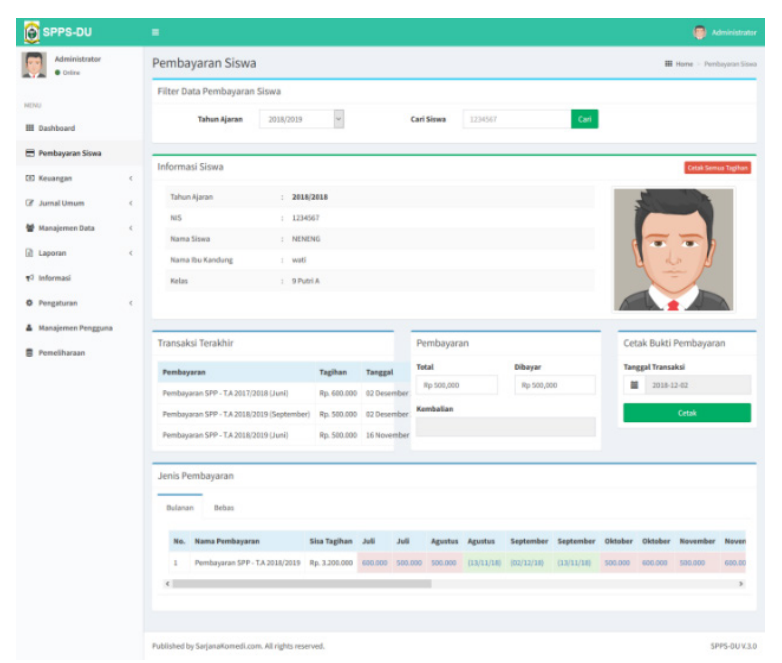

Figure 3. Database of student fees
Information technology is slowly eliminating existing problems. By using the application for payment, you will avoid the following matters: long queues, inadequate clerk, lack of security, difficulty making reports, and lost document.

\section{b. digital library}

Digital libraries can be considered as information institutions in new forms or as extensions of existing library services. However, digital libraries as managed information collections, which have related services, information is stored in digital format and can be accessed through the network.

The application of IT in the field of library services can be seen from several things such as:

1) Circulation Services

The application of IT in the field of circulation services can include many things including loan and repayment services, user statistics, membership administration, etc. Besides that, cross-service between libraries can also be done which is easier to do if information technology has become part of this circulation service. Current technology has made it possible for selfservices in circulation services through barcoding and RFID (Radio Frequency Identification) facilities. The application of communication technology has begun to be used as the use of SMS, Facsimile, and the Internet.

2) Reference Services \& Research Results

The application of IT in reference services and research results can be seen from the availability of access to browse electronic/digital reference sources and other library materials through electronic dictionaries, electronic directories, electronic maps, research results in digital forms, and others.

3) Journal / Magazine / Periodic Services

Journal, magazine service users will be greatly helped if the library can provide easy access to electronic journals, both of which are accessed from local, global databases and those available in Compact Disk and Diskette formats. Even cross-service and information retrieval services can be used by users with the help of information technology such as the internet.

4) Multimedia / Audio-Visual Services

Multimedia / audio-visual services that are used to be better known as "non-book material" services are services that are directly in contact with information technology. In this service, users can take advantage of information technology in the form of Video Cassettes, Audio Cassettes, MicroFilm, MicroFische, Compact Disks, Laser Disks, DVDs, Home Movies, Home Theater, etc.

This service also allows for interactive media that can be used by users to do learning, etc. Another thing to note in the library services is users who have limitations, such as poor vision, blindness, lack of hearing, and other disabilities. Multimedia / Audio- 
Visual services allow libraries to provide services to users with these criteria. As an example of the form of application of technology for that is Audible E-books, Digital Audio Books, Info Eyes (Virtual Reference), Braille, etc.

5) Internet \& Computer Station Services

The internet is now a "star" in information technology. People are already familiar with using the internet in their lives. For this reason, inevitably the library must be able to provide services through this media.

Through the web media, the library provides information and services to its users. Besides that, the library can also provide internet access using either a computer station or WIFI / Access Point that users can use as part of the services provided by the library.

\section{CONCLUSION}

Technology-based education management is needed to provide information to support and simplify the management process. Information Technology is an important factor for improving services while saving for education and has now become one of the quality standards of an Education. Technology-based education management provides outputs from information management systems in the form of plans and budgets, scheduled reports, special reports, analysis of problem situations, decisions for review, and answers to questions.

In the management of vocational secondary education, Management Information Systems are meant to provide facilities for School Institutions (Students, Teachers, Organizing School Administration), Parents / Guardians of Students, Government (Ministry of National Education), Other Parties (Government and private institutions, NGO or any party that requires information on educational data) in obtaining information. Besides, there are also applications of school websites, e-learning, and digital libraries that develop according to the needs of vocational secondary education.

\section{REFERENCES}

Barta, B. Z. \& Telem, M. (1997). Internet Support to School Innovation Management. In Information Technology in Educational Management for the Schools of the Future, A. C. W. Fung et al. (Eds.), pp. 7-14. Springer.

Dahil, L., Karabulut, A., \& Mutlu, İ. (2015). Reasons and Results of Nonapplicability of Education
Technology in Vocational and Technical Schools in Turkey. Procedia - Social and Behavioral Sciences, 176, 811-818. https://doi.org/https://doi. org/10.1016/j.sbspro.2015.01.544

Agus, A., \& Saygın, Y. (2019). Privacy perception and information technology utilization of high school students. Heliyon, 5, (5), e01614. https://doi. org/10.1016/j.heliyon. 2019.e01614

Hamalik, O. (2007). Manajemen Pengembangan Kurikulum. Bandung: PT. Remaja Rosda Karya.

Hornby, A.S. (1995). Oxford Advanced Learner's Dictionary. Oxford: Oxford University Press

Koswara, E. (2015). Konsep Pendidikan Tinggi Berbasis E-learning: Peluang dan Tantangan. Prosiding Konferensi Nasional Teknologi Informasi dan Komunikasi Indonesia ITB, 3-4 Mei 2005.

Mäkelä, M. (1997). Information Technology - A Tool and An Obstacle in the Education of the Future. In Information Technology in Educational Management for the Schools of the Future, A. C. W. Fung et al. (Eds.), pp. 23-30. Springer.

Lantip, P. D. \& Riyanto. (2011). Teknologi Informasi Pendidikan. Yogyakarta: Gava Media.

Oetomo, B. S. D dan Priyogutomo, J. (2004). Kajian Terhadap Model e-Media dalam Pembangunan Sistem e-Education, Paper presented in Seminar Nasional Informatika 2004, Universitas Ahmad Dahlan Yogyakarta on 21 Februari 2004.

Telem, M., Barta, B.Z. and Levin, K.D. (1997). Information Educational Tomorrow's Technology in Management of School. In In Information Technology in Educational Management for the Schools of the Future, A. C. W. Fung et al. (Eds.), pp. 31-40. Springer.

Tilaar, H. A. R. (2012). Kaleidoskop Pendidikan Nasional. Jakarta: PT Kompas Media Nusantara.

UU Nomor 20 Tahun 2003. (2003). Undang-Undang No.20 Tahun 2003. Departemen Pendidikan Nasional.

Warsita, B. (2008). Teknologi Pembelajaran Landasan dan Aplikasinya. Jakarta: PT Rineka Cipta.

Williams dan Sawyer. (2003). Using Information Technology: A Practical. Introduction to Computers and Communications. London: Career. 